\title{
Students' thought pattern concerning the greenhouse effect
}

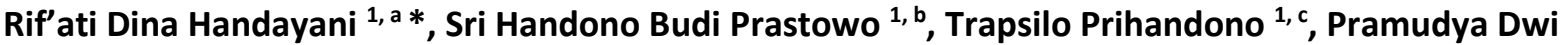 \\ Aristya Putra ${ }^{1, \mathrm{~d}}$, Rayendra Wahyu Bachtiar 1, 2, e, Lailatul Nuraini 1, f, Bambang Supriadi 1, g, Maryani \\ Maryani ${ }^{1, h}$, Singgih Bektiarso ${ }^{1, \mathrm{i}}$, Albertus Djoko Lesmono ${ }^{1, \mathrm{j}}$, I Ketut Mahardika ${ }^{1, \mathrm{k}}$ \\ ${ }^{1}$ Universitas Jember. Jalan Kalimantan No. 37, Kampus Tegalboto, Jember, Jawa Timur, 68121, Indonesia \\ 2 Utrecht University. Heidelberglaan 8, 3584 CS Utrecht, The Netherlands \\ a rifati.fkip@unej.ac.id, b srihandono.fkip@unej.ac.id, c trapsilo.fkip@unej.ac.id, d pramudya.fkip@unej.ac.id, \\ e rayendra_fkip@unej.ac.id, ${ }^{f}$ lailatul.fkip@unej.ac.id, ${ }^{\mathrm{g}}$ bambangsupriadi.fkip@unej.ac.id, \\ h maryani.fkip@unej.ac.id, i singgih.fkip@unej.ac.id, jalbert.fkip@unej.ac.id, kiketutmahardika202@gmail.com \\ * Corresponding Author.
}

Received: 18 November 2020; Revised: 20 December 2020; Accepted: 10 January 2021

\begin{abstract}
This study aims at investigating the Physics students' thought patterns concerning the greenhouse effect. Descriptive analysis was used, including the set of qualitative data. These data were then interpreted for their idea and content inductively to recognize students' thoughts and models concerning the greenhouse effect. The result confirmed three patterns of the students' thoughts concerning the greenhouse effect (patterns $A, B$, and $\mathrm{C}$ ). The model covered different concepts, mechanisms, and processes of the greenhouse effect. The students' knowledge from science teacher explanations and books is not the only learning source concerning the educational environment. The issue and broadcast media frequently carry out confusing the concepts. This research is expected to provide physics teachers critical information to develop appropriate teaching methods and strategies concerning these topics.

Keywords: students' thoughts pattern, the greenhouse effect, environmental issue, climate system.
\end{abstract}

How to Cite: Handayani, R. D., Prastowo, S. H. B., Prihandono, T., Putra, P. D. A., Bachtiar, R. W., Nuraini, L., Supriadi, B., Maryani, M., Bektiarso, S., Lesmono, A. D., \& Mahardika, I. K. (2021). Students' thought pattern concerning the greenhouse effect. Momentum: Physics Education Journal, 5(1), 21-28. https://doi.org/10.21067/mpej.v5i1.5156

\section{Introduction}

The climate issue is a fundamental problem facing global society and has become the most significant environmental challenges in the 21st Century. Regulating climate change issues requires involving all participants globally (Stevenson, 2007). Human activities would change the regularity of the environmental system (Akintunde, 2017). The greenhouse effect is a scientific phenomenon that includes complex processes. The process is not directly observed, thus it may be challenging and confusing to understand and believe (Jackson \& Pang, 2017; Schreiner et al., 2005). Climate issues such as the greenhouse effect have been added to the science curriculum. The greenhouse effect study is carried out at both the formal and informal levels. Environmental education must develop an adequate understanding of every student (Hansen, 2010; Palmer, 2002; Stevenson, 2007).

Teaching and learning is an integral aspect of transforming and organizing people in order to reside in more comfortable and safe environments (Dewi et al., 2012; Shepardson et al., 2009). Gola (2017) believed that the school needs to deal with climate change and familiarize it with its influence. Schools should encourage students to find out about environmental issues, consequences, and procedures to be taken to overcome (Shepardson et al., 2009) and participate in the action managing the environmental problem by taking into account the capacity of students (Ocal et al., 2011). 
Building student awareness of climate concerns must be a consideration to effectively minimize the causes and impacts of environmental problems (Stevenson, 2007). Studying climate change offers a real framework for the consideration of science through individual and social interactions that potential people have a responsibility to ensure the survival of the environment (Bélanger, 2003; Shepardson et al., 2012). People who may not understand the vital role of the greenhouse effect on the climate system are encouraged to reduce carbon emissions that confirm the number of built-in greenhouse gases. The aim of this study is to investigate the design patterns of students with regard to the greenhouse effect. This research finding also presents the design and thinking patterns of students related to the greenhouse effect.

\section{Method}

This study was conducted in public schools of senior high school in Jember. The number of participants was 36 students in the eleventh-grade levels. The class was chosen since it was appropriate for the research purpose and homogenous. There were 30 females $(83.33 \%)$ and six males $(16.67 \%)$, with the students' age range, which was $15-16$ years. The study was limited data about the learner's social, cultural, and how these might affect their answers. Data were gathered as the assessment instrument of the test with valid criteria of 0.87 . The assessment consisted of two items: the conception of the greenhouse effect and the impact. The questions are designed in such a way hence students focus more on the processes and mechanisms involved in the greenhouse effect scientifically. The student answers are not scored as "true" or "false" but it held, examined for the content knowledge. The participant addressed their response and expressed their conceptual knowledge, fulfilled by meaning. Pupils were writing, and sketches draw their thought, excitement, engagement, motive, and perspectives (Kress et al., 2014).

These data were then examined for the content to identify the ideas and design of students' thinking inductively. The interpretative evaluation needed an inductive procedure, such as exploring pre-determined models and forming a topic of point (Johnson \& Christensen, 2013). All student responses were scanned frequently and examined to determine the research problem and find their thinking pattern concerning the greenhouse effect. During this process, schemes are developed regarding how to represent participant responses. From the first reading, the primary concept was identified and recognized. The researcher noticed the meant students' response that appropriates with research context. The critical data and information were organized and interpreted initially and then corrected for the second reading. This process was established to check the data for obstruction and reduce irrelevant information. The final findings obtained were three students' thought patterns related to the greenhouse effect, including pattern $A$, pattern $B$, and pattern $C$, compiled from students' response analysis. This independent developing design process presented a degree of triangulation, diminishing preference, subjectivity, and improving the validity (Calderon, 2011; Creswell, 2012).

\section{Result}

\section{Result and Discussion}

From the scientific perspective, most participants took additional scientific and logical understanding regarding the greenhouse effect. Based on the investigation of students' responses, three patterns of student thinking about the greenhouse effect are found: design A, design B, and design $\mathrm{C}$.

Design A

Figure 1 was constructed from 12 students' responses (33.3\%). Design A illustrated that the earth is surrounded by the atmosphere. Human activities such as progressive deforestation, burning fossil fuel raised greenhouse gas concentrations $\left(\mathrm{CO}_{2}, \mathrm{CH}_{4}, \mathrm{~N}_{2} \mathrm{O}\right.$, and $\left.\mathrm{CFCS}\right)$ in the atmosphere. Greenhouse gases and other air pollutants will further establish a thin layer of glass at a certain altitude and act as a cover around the earth. When the solar heat reaches the atmosphere, some heat will be 
reflected into space, and part of it will be absorbed and enter the earth. This heat will be absorbed by the earth, such as plants, sea, and land. While some of which will be reflected and absorbed with the greenhouse gasses. A layer of greenhouse gases traps the heat reflected by the earth and re-reflected back to earth. This process occurs continuously cause the temperature on earth is getting warm up. Here an example of students' answers in the text and picture (Figure 2).

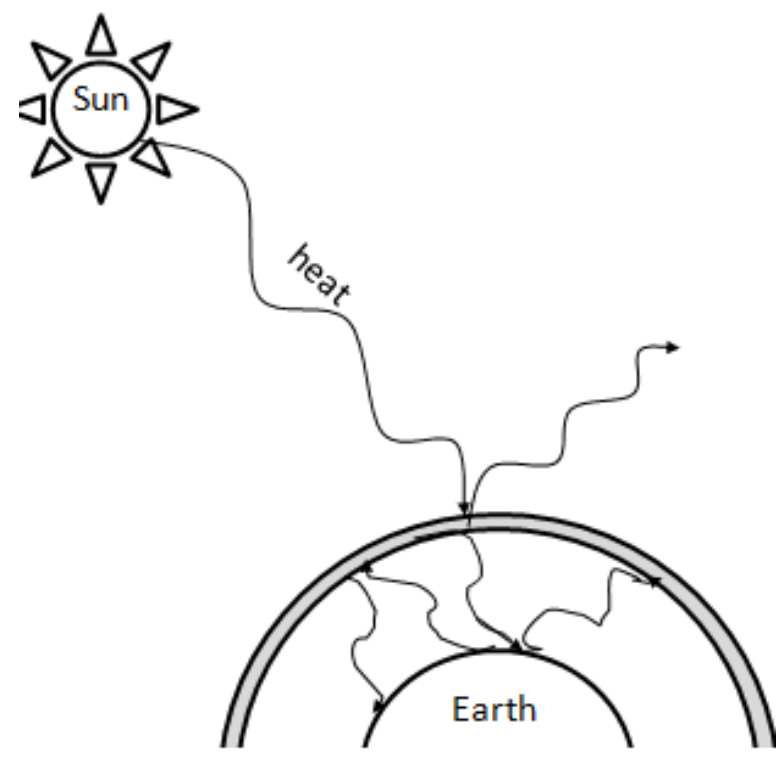

Figure 1. Design A

Heat energy (solar heat) that enters through the atmosphere forms like a glass layer, partly reflected out of the atmosphere and partly trapped into the atmosphere, increasing its temperature. In the greenhouse effect, some gases reach the layer that covers the earth. This gas is in the form of carbon dioxide (CO2), methane ( $\mathrm{CH} 4)$, dinitrogen dioxide (N2O), called greenhouse gasses. If this greenhouse effect gas is released, the greenhouse gasses will rise to the stratosphere and form a layer covering the earth. This causes earth heat to bounce off and must be carried out. This heat causes the earth's temperature rises and make heats globally, which is known as global warming (SA_1)

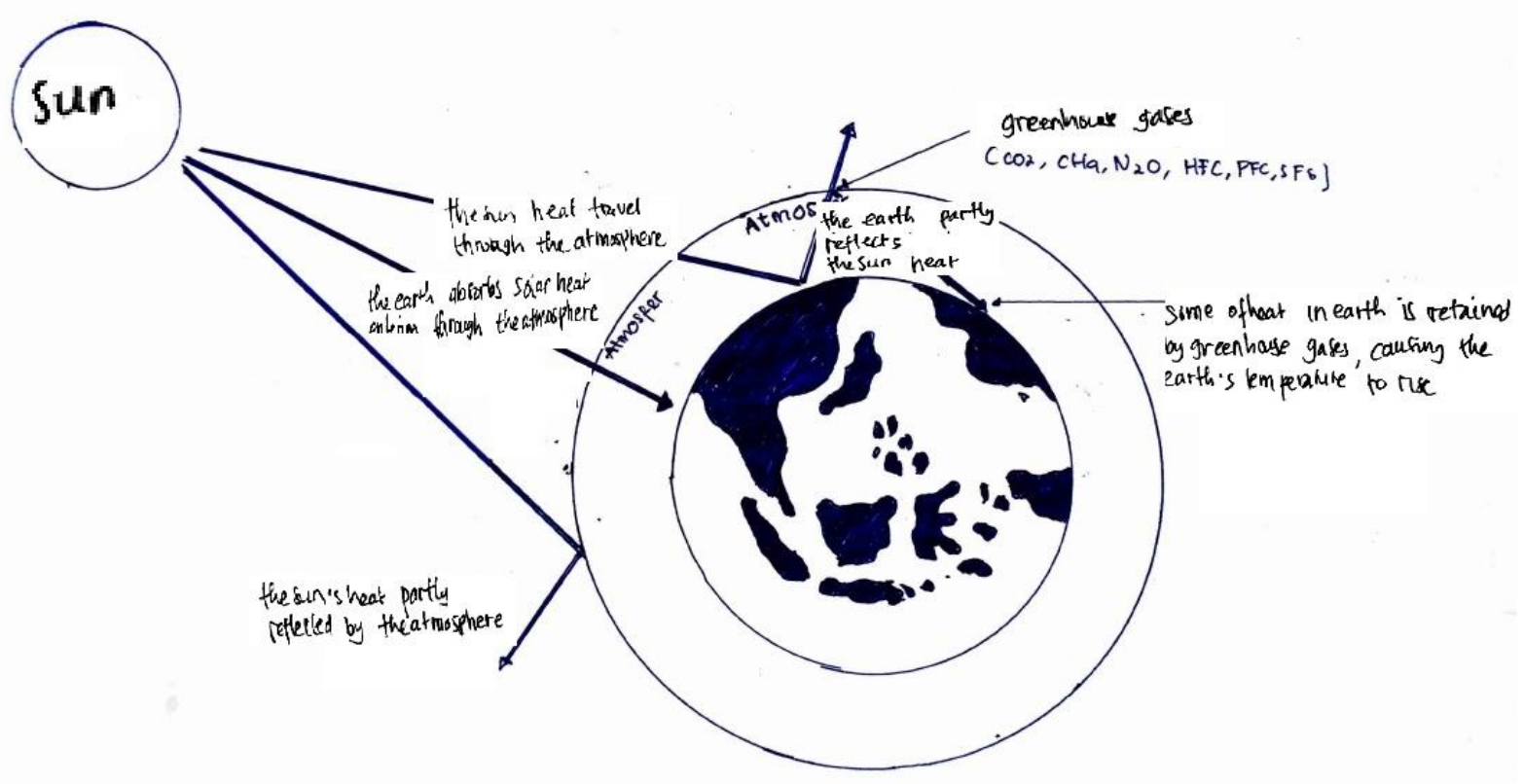

Figure 2. Example of students' drawing (FI_1) 
Design $B$

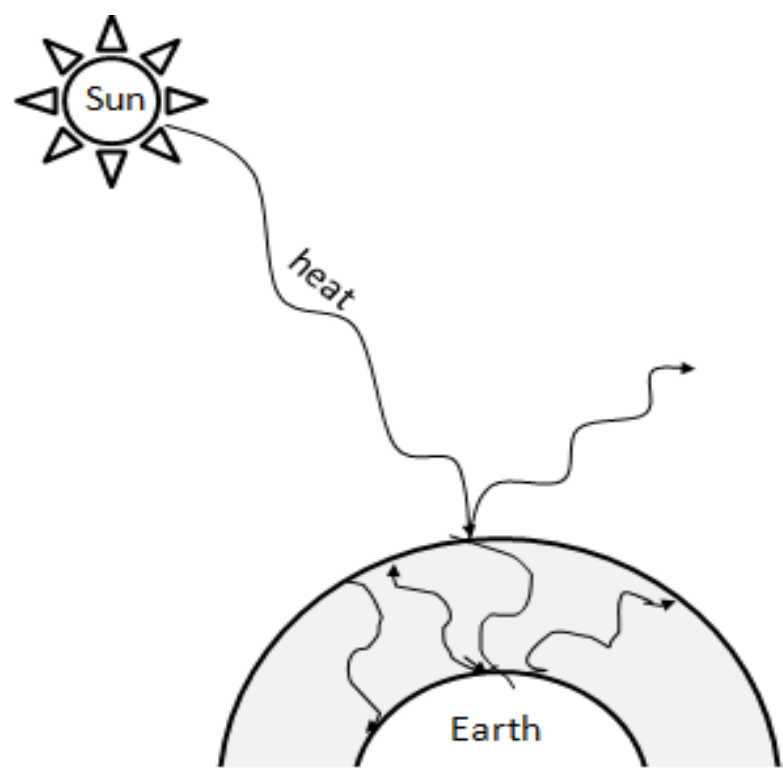

Figure 3. Design B

Figure 4 is created from 15 students' opinions (41.7\%). Design B pattern illustrated that solar heat reaches the outer layer of the earth's atmosphere. Some of this heat will be reflected, and some will be transmitted. The heat transmitted will be absorbed by the greenhouse gases $\left(\mathrm{CO}_{2}, \mathrm{~N}_{2} \mathrm{O}, \mathrm{CH}_{4}\right)$ that uniformly spread out in the atmosphere. Greenhouse gasses will be re-emit the heat to the atmosphere. The absorption and reflection of heat by greenhouse gases repeatedly occur in the atmosphere, which causes the rise of the earth's temperature. The following is an example of students' responses in the form of written and drawing (Figure 4).

The greenhouse effect is a natural process that occurs when gases from the earth's atmosphere absorb the heat from the sun. The cause of the greenhouse effect is greenhouse gases, namely $\mathrm{CO} 2, \mathrm{CH} 4, \mathrm{N2O}, \mathrm{CFC}$ in the atmosphere, which absorb heat. The majority of greenhouse gases are $\mathrm{CO} 2$ from fossil fuels' burning, such as cars, factories, and motorcycles. This trapped heat causes the earth's temperature to warm (CLK_2)

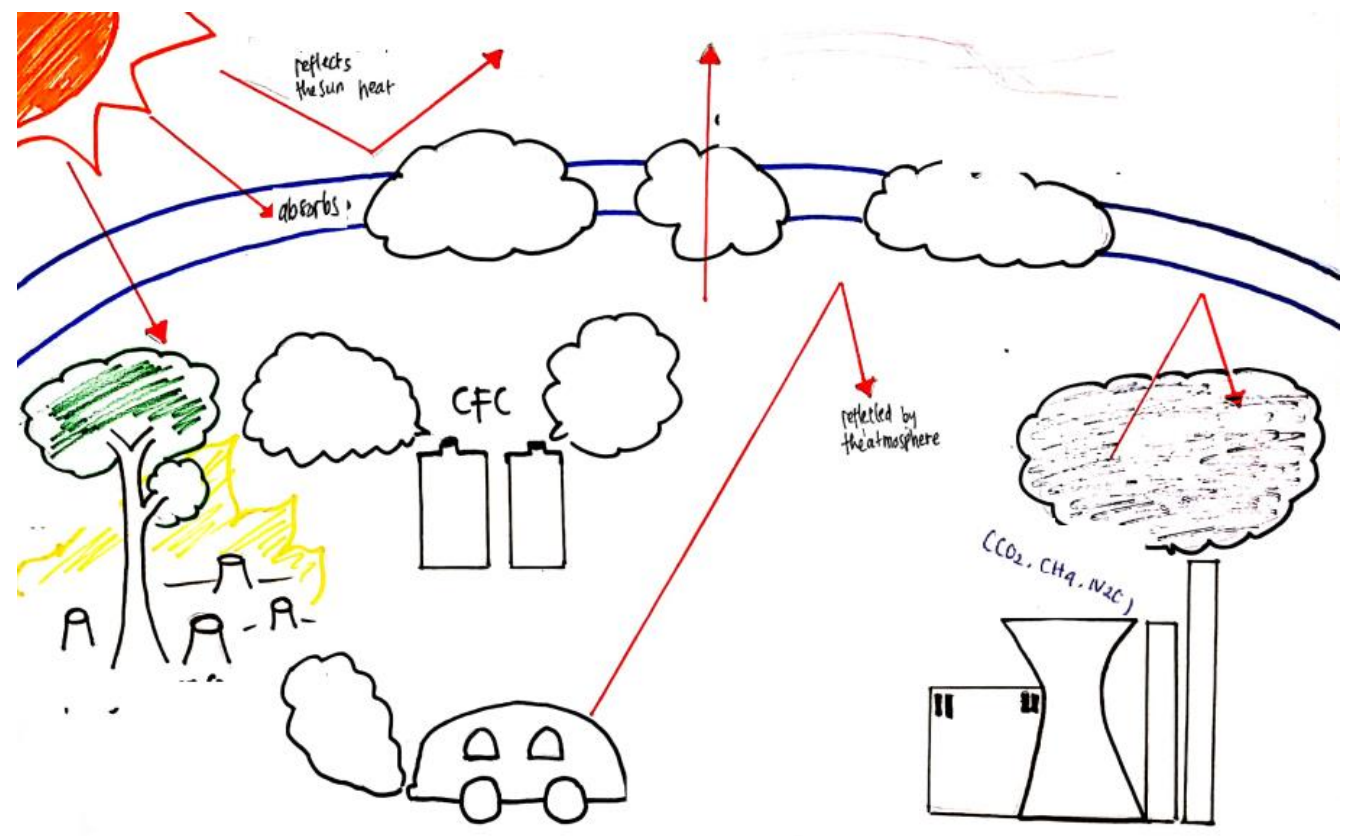

Figure 4. Example of students' drawing (OTA_2) 
Design C

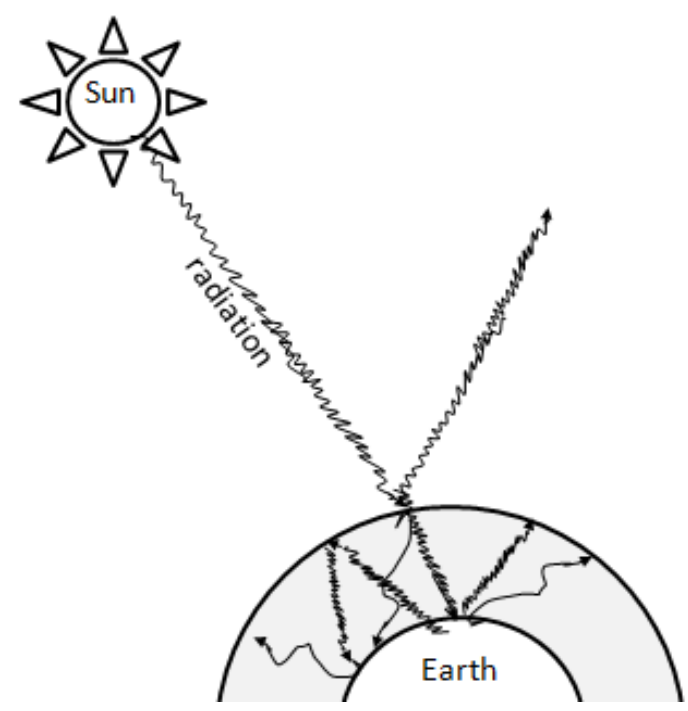

Figure 5. Design C

Figure 5 was constructed from nine students' answers (25\%). Design C explained that when the sun's radiation reaches the earth's atmosphere, partially absorbed and partly reflected. Radiation emitted by the sun is a varying form of ultraviolet, infrared, and visible light. When radiation reaches the earth's ozone layer, ultraviolet radiation will be reflected. Part of the radiation that enters the earth's atmosphere will be absorbed by the earth's surface, such as plants, land, and the sea, and partly radiation in the form of infrared will interact with greenhouse gases $\left(\mathrm{CO}_{2}, \mathrm{~N}_{2} \mathrm{O}\right.$, methane). The greenhouse gases will absorb and re-radiate heat energy in all directions to the earth. This heat energy is trapped in the atmosphere, blocking it from escaping into space and causes the rise of the earth's temperature. The following text and drawing (Figure 6) is an example of students' responses.

The greenhouse effect occurs because the sun emits its rays in the form of ultraviolet radiation to the earth, which will be received by the earth's atmosphere. Some of the radiation will be reflected as high-energy radiation (ultraviolet) and partly absorbed and transmitted by the atmosphere. This transmitted radiation in infrared emission will be trapped by greenhouse gases such as $\mathrm{CO} 2, \mathrm{CH} 4, \mathrm{N2O}$, and others in the atmosphere. The trapped radiation will cause the earth's temperature to warm (KM_1).

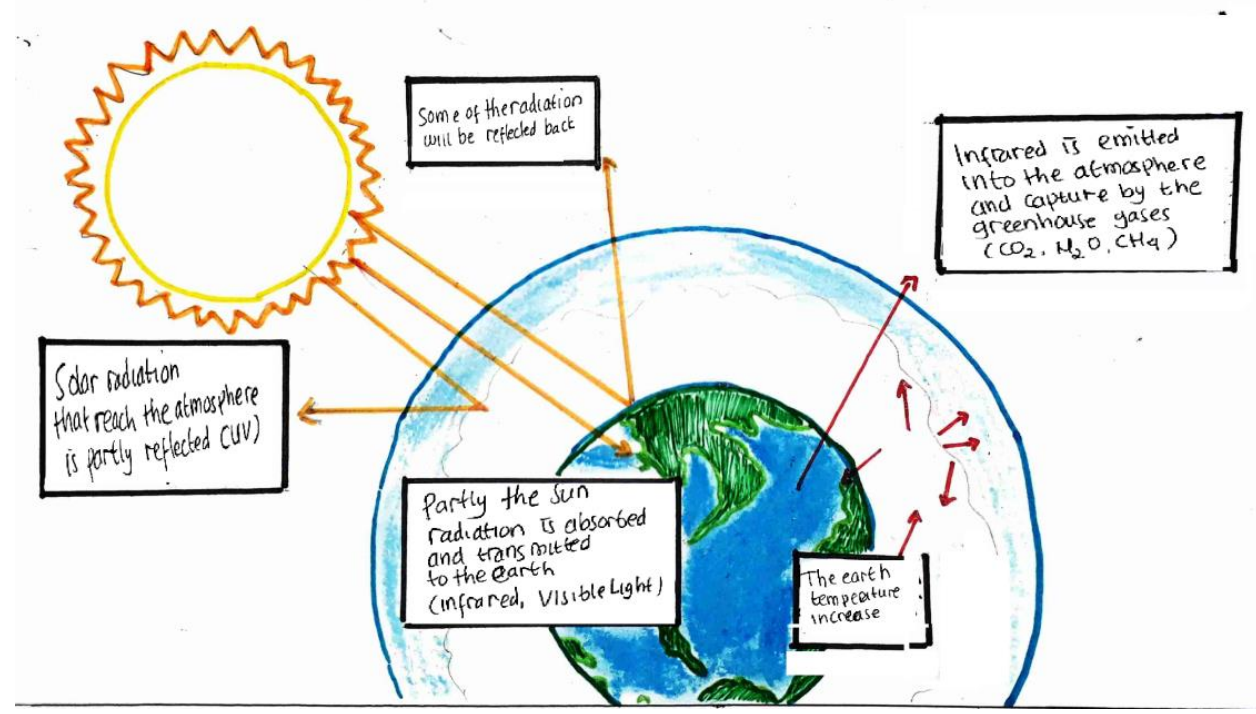

Figure 6. Example of students' drawing (APN_2) 


\section{Discussion}

The greenhouse effect is revealed by heat trapped between the atmosphere and the earth's surface. The heat comes from the sun that emits various radiation types, such as ultraviolet, infrared, and visible light. Greenhouse gases such as carbon dioxide $\left(\mathrm{CO}_{2}\right)$, nitrous oxide $\left(\mathrm{N}_{2} \mathrm{O}\right)$, methane $\left(\mathrm{CH}_{4}\right)$, and water vapor in the atmosphere interact with the radiation of infrared and prevent escape from space (Andersson \& Wallin, 2000; Koulaidis \& Christidou, 1999; Pruneau, Gravel, Bourque, \& Langis, 2003). The greenhouse gasses are permeable to incoming short-wave, but they actively absorb and re-radiate long-wave thermal radiation. It causes the earth's temperature to grow warmer likely. The greenhouse effect is significant for the sustainability and survival of living things of humans, plants, and animals on the earth (Sterling, 2010; Svihla \& Linn, 2012; Tolppanen \& Aksela, 2018).

The majority of participants remained a further scientific understanding concerning the greenhouse effect. They identified $\mathrm{CO}_{2}, \mathrm{CH}_{4}, \mathrm{~N}_{2} \mathrm{O}$ as greenhouse gasses but did not identify and recognize other greenhouse gases such as water vapor. Besides, there is a misconception that students have. They cannot distinguish between solar heat and radiation and believe that the greenhouse effect negatively impacts climate change and causing global warming. Harrington (2008) also indicated that several of his participants had verified the negative consequences and mistaken perception about the phenomenon. Fundamental misconceptions and misinformation about climate science are firmly taken by students, teachers, and public audiences (McCaffrey \& Buhr, 2008). Also, several previous research has reported students' thinking concerning the greenhouse effect involves: (1) an interpretation that the greenhouse effect is an environmental problem and neglecting the fact that it is a natural phenomenon, (2) a presumption that human activities made the greenhouse effect, and (3) missing the water vapor as greenhouse gasses (Jafer, 2020). The crucial issues on climate change, the greenhouse effect, and global warming are the complex interaction between humans and the environment (Inaotombi \& Mahanta, 2018). This misconception and misinformation need to be corrected by the teacher by providing a complete understanding and associating it with previous learning.

The student thinking pattern concerning the greenhouse effect was constructed from the participant answers. The patterns include different concepts, mechanisms, and processes about the greenhouse effect. Students' conception patterns confirmed that students' thinking varies. The three patterns are designed to present different students' thoughts on the greenhouse effect's topic. The students' knowledge from science teacher explanations and books at school is not the only learning source concerning the educational environment. Additional factors such as television, electronic media, and other social media that discuss the greenhouse effect also affect students' knowledge. The issue and broadcast media frequently carry out a confusing and challenging idea concerning the greenhouse effect and global warming (Kress et al., 2014; Schreiner et al., 2005). Studying the greenhouse effect topic challenges teachers' creativity to formulate, illustrate, and manage the learning strategies (Koulaidis \& Christidou, 1999; Schreiner et al., 2005). Educating students about environmental education is challenging for science teachers since its interdisciplinary and complex issues. This study recommends further research regarding the media's influence on students' thinking patterns and understanding of the greenhouse effect and global warming.

\section{Conclusion}

The students' thought patterns about the greenhouse effect were constructed from the students' answers. The first, second, and third patterns hold different concepts, mechanisms, and processes concerning the greenhouse effect. In this research, the student cannot distinguish between solar heat and radiation and believe that the greenhouse effect negatively impacts the climate system and causing global warming. The greenhouse effect is an invisible phenomenon that cannot be directly observed and hard to understand. Learning about environmental issues of the greenhouse effect is challenging for science teachers since its complex issues. This research is expected to give physics teachers critical information to develop appropriate teaching methods and strategies concerning these topics. 
Momentum: Physics Education Journal, 5 (1), 2021, 27

Rif'ati Dina Handayani et al

\section{Acknowledgment}

This research was funded by the University of Jember through a research group grant (KeRis batch 1).

\section{References}

Akintunde, E. A. (2017). Theories and concepts for human behavior in environmental preservation. Journal of Environmental Science and Public Health J Environ Sci Public Health, 1(2), 120-133. https://doi.org/10.26502/JESPH.012

Andersson, B., \& Wallin, A. (2000). Students' understanding of the greenhouse effect, the societal consequences of reducing $\mathrm{CO} 2$ emissions and the problem of ozone layer depletion. Journal of Research in Science Teaching, 37(10), 1096-1111. https://doi.org/10.1002/10982736(200012)37:10<1096::AID-TEA4>3.0.CO;2-8

Bélanger, P. (2003). Learning environments and environmental education. New Directions for Adult and Continuing Education, 2003(99), 79-88. https://doi.org/10.1002/ace.112

Calderon, J. L. (2011). How-To Data Collection Series: The Evolution of the Focused Discussion Group-From Non-Participant to One of the Crew. Qualitative Report, 16(1), 308-311. http://www.nova.edu/ssss/QR/QR16-1/calderon.pdf

Creswell, J. W. (2012). Educational research: Planning, conducting, and evaluating quantitative and qualitative research (Vol. 1). Pearson. http://basu.nahad.ir/uploads/creswell.pdf

Dewi, J. K., Hendarti, L., Matakupan, S., \& Lisdiyanta, T. (2012). Suplemen pembelajaran perubahan iklim untuk guru (Climate change learning supplements for teachers). Kementerian Lingkungan Hidup.

Gola, B. (2017). Is formal environmental education friendly to nature? Environmental ethics in science textbooks for primary school pupils in Poland. Ethics and Education, 12(3), 320-336. https://doi.org/10.1080/17449642.2017.1343619

Hansen, P. J. K. (2010). Knowledge about the greenhouse effect and the effects of the ozone layer among norwegian pupils finishing compulsory education in 1989, 1993, and 2005-what now? International Journal of Science Education, 32(3), 397-419. https://doi.org/10.1080/09500690802600787

Harrington, J. (2008). Misconceptions: Barriers to improved climate literacy. Physical Geography, 29(6), 575-584. https://doi.org/10.2747/0272-3646.29.6.575

Inaotombi, S., \& Mahanta, P. C. (2018). Pathways of socio-ecological resilience to climate change for fisheries through indigenous knowledge. Human and Ecological Risk Assessment: An International Journal, 24, 1-13. https://doi.org/10.1080/10807039.2018.1482197

Jackson, L., \& Pang, M. (2017). Secondary school students ' views of climate change in Hong Kong. International Research in Geographical and Environmental Education, 26(3), 180-192. https://doi.org/10.1080/10382046.2017.1330036

Jafer, Y. J. (2020). Assessing Kuwaiti pre-service science teachers' Greenhouse effect perceptions and misconceptions. International Journal of Science and Mathematics Education, 18(4), 657-667. https://doi.org/10.1007/s10763-019-09992-1

Johnson, R. B., \& Christensen, L. B. (2013). Educational research: Quantitative, qualitative, and mixed approaches (5 edition). SAGE Publications, Inc.

Koulaidis, V., \& Christidou, V. (1999). Models of students' thinking concerning the greenhouse effect and teaching implications. Science Education, 83(5), 559-576. https://doi.org/10.1002/(SICI)1098-237X(199909)83:5<559::AID-SCE4>3.0.CO;2-E

Kress, G. R., Jewitt, C., Ogborn, J., \& Tsatsarelis, C. (2014). Multimodal teaching and learning : the rhetorics of the science classroom. Bloomsbury.

McCaffrey, M. S., \& Buhr, S. M. (2008). Clarifying climate confusion: Addressing systemic holes, cognitive gaps, and misconceptions through climate literacy. Physical Geography, 29(6), 512- 
528. https://doi.org/10.2747/0272-3646.29.6.512

Ocal, A., Kisoglu, M., Alas, A., \& Gurbuz, H. (2011). Turkish prospective teachers' understanding and misunderstanding on global warming. International Research in Geographical and Environmental Education, 20(3), 215-226. https://doi.org/10.1080/10382046.2011.588504

Palmer, J. (2002). Environmental education in the 21st century. Routledge. https://doi.org/10.4324/9780203012659

Pruneau, D., Gravel, H., Bourque, W., \& Langis, J. (2003). Experimentation with a socio-constructivist process for climate change education. Environmental Education Research, 9(4), 429-446. https://doi.org/10.1080/1350462032000126096

Schreiner, C., Henriksen, E. K., \& Kirkeby Hansen, P. J. (2005). Climate education: Empowering today's youth to meet tomorrow's challenges. Studies in Science Education, 41(1), 3-49. https://doi.org/10.1080/03057260508560213

Shepardson, D. P., Niyogi, D., Choi, S., \& Charusombat, U. (2009). Seventh grade students' conceptions of global warming and climate change. Environmental Education Research, 15(5), 549-570. https://doi.org/10.1080/13504620903114592

Shepardson, D. P., Niyogi, D., Roychoudhury, A., \& Hirsch, A. (2012). Conceptualizing climate change in the context of a climate system: implications for climate and environmental education. Environmental Education Research, 18(3), 323-352. https://doi.org/10.1080/13504622.2011.622839

Sterling, S. (2010). Learning for resilience, or the resilient learner? Towards a necessary reconciliation in a paradigm of sustainable education. Environmental Education Research, 16(5-6), 511-528. https://doi.org/10.1080/13504622.2010.505427

Stevenson, R. B. (2007). Schooling and environmental/sustainability education: from discourses of policy and practice to discourses of professional learning. Environmental Education Research, 13(2), 265-285. https://doi.org/10.1080/13504620701295650

Svihla, V., \& Linn, M. C. (2012). A design-based approach to fostering understanding of global climate change. International Journal of Science Education, 34(5), 651-676. https://doi.org/10.1080/09500693.2011.597453

Tolppanen, S., \& Aksela, M. (2018). Identifying and addressing students' questions on climate change. The Journal of Environmental Education, 49(5), 375-389.

https://doi.org/10.1080/00958964.2017.1417816 